Endocrinol. Japon. 1984, 31 (2), 177-184

\title{
Cholesterol Accumulation in Adrenocortical Mitochondria after ACTH-stimulation
}

\author{
SACHIKo MUKAI, Mitsuhiro OKAMOTO, Toshio YAMANO, \\ KAZUNORI ISHIMURA* AND HISAO FUJITA* \\ Department of Biochemistry, Osaka University Medical School and \\ *Department of Anatomy, Osaka University Medical School \\ 4-3-57, Nakanoshima, Kitaku, Osaka 530
}

\begin{abstract}
Rat adrenocortical cell suspensions $\left(10^{6}\right.$ cells) were incubated with ACTH $(40 \mathrm{nM})$ in $2 \mathrm{ml}$ of Krebs-Ringer bicarbonate buffer for $90 \mathrm{~min}$. About 42 nmol of corticosterone and $14 \mathrm{nmol}$ of 18-hydroxydeoxycorticosterone were generated and released into the medium. Aminoglutethimide at $50 \mu \mathrm{M}$ inhibited the steroidogenesis to $16 \%$. Mitochondrial pellets were prepared from the cells incubated in the absence, or in the presence, of ACTH and aminoglutethimide, and cholesterol content was determined. The mitochondria of the cells incubated without the drugs contained $25.2 \mu \mathrm{g}$ cholesterol $/ \mathrm{mg}$ protein. Cholesterol content increased by $10 \%$ in the mitochondria of the ACTHstimulated cells. The mitochondria of the cells incubated in the presence of both ACTH and aminoglutethimide contained $143 \%$ of cholesterol compared to those of the nontreated cells. When rats were subjected to ether stress after aminoglutethimide pretreatment, cholesterol content of the mitochondrial fraction increased to about $200 \%$ compared to that of the control rats. These results suggest that a cholesterol pool exists in the adrenocortical mitochondria and that the amount increases during the steroidogenic stimulation of the cells. The mitochondria were fixed with filipin-containing fixative and examined by freeze-fracture electron microscopy. Accumulations of filipin-cholesterol complexes were observed in the inner membrane of the mitochondria as protuberances or pits $25 \mathrm{~nm}$ in diameter.
\end{abstract}

Mitochondria of steroidogenic tissues contain a cholesterol side chain cleavage enzyme, cytochrome $\mathrm{P}-450_{\mathrm{scc}}$, in their inner membrane, and either a reaction catalyzed by this enzyme system or transport of cholesterol to the enzyme catalytic site through the mitochondrial membrane is believed to be a rate-determining step in steroidogenesis (Garren et al., 1971 ; Kimura, 1981 ; Schu1ster, 1974; Simpson, 1979; Stone and

Received January 10, 1984
Hechter, 1954). This poses an interesting question about the status of cholesterol in the mitochondria of these tissues, because the mitochondria of nonsteroidogenic tissues are known not to contain much cholesterol in their membrane. Where cholesterol is localized in the subfraction of adrenocortical mitochondria and how it is transported to the catalytic site of cytochrome $\mathrm{P}-450_{\mathrm{scc}}$ have been major questions inquired into by a number of biochemists and endocrinologists (Mahaffee et al., 1974 ; Simpson et al., 1978). 
For instance, Privalle et al. (1983) observed that cholesterol accumulates in the mitochondrial fractions of rat adrenal glands during ether stress when the animal is pretreated with aminoglutethimide. Kido and Kimura (1981) and Ohno et al. (1983) discussed the nature of a labile protein factor which could help cholesterol to move into the mitochondrial inner membrane and to place itself in the catalytic site of the enzyme. Crivello and Jefcoate (1980) reported participation of microtubules and microfilaments in achieving the appropriate transportation of cholesterol, while Hall et al. (1981) discussed a role of calmodulin in the same process.

It has been known that a polyene antibiotic, filipin, can specifically bind to membrane cholesterol and form filipin-sterol complexes (De Kruijff and Demel, 1974; Kinsky, 1970 ; Norman et al., 1976). These complexes are easily recognized in freezefracture images as protuberances or pits 25-30 nm in diameter (Fujita et al., 1981; Fujita et al., 1982; Matsuda et al., 1983; Montesano, 1979; Nakajima and Bridgman, 1981). Although a number of studies have recently been carried out on the distribution of cholesterol in plasma-and cyto-membranes of various organs using freeze-fracture images of filipin-treated tissues, no information is yet available about this subject of adrenocortical mitochondria.

In order to confirm the results of previous studies on cholesterol movement in adrenocortical cells and to obtain morphological information about the presence of cholesterol in the mitochondria, we have chemically analyzed the cholesterol content in the adrenocortical mitochondria during the steroidogenic stimulation of the cells in vivo and in vitro, and, at the same time, have microscopically observed the presence of filipincholesterol complexes in the mitochondria of these cells.

\section{Materials and Methods}

\section{Animals and Chemicals}

Female Sprague-Dawley rats, weighing 160$180 \mathrm{~g}$, were used throughout this study. Synthetic $\mathrm{ACTH}_{1-24}$, Cortrosyn, was obtained from Daiichi Seiyaku, Co. Aminoglutethimide was a gift from Ciba-Geigy, Co. Collagenase (Type I) and deoxyribonuclease were purchased from Worthington and Sigma, respectively. Steroids were products of either Makor Chemicals or Steraloids. Filipin was generously donated by the Upjohn Co., Kalamanzoo, Mich. All other chemicals were from local sources and of the highest purity available commercially.

\section{Preparation of Adrenocortical Cell Suspensions}

The cell suspensions were prepared from rat adrenal glands as described by Haning et al. (1970) with some modification. At a time between 8 and $10 \mathrm{am}$, rats were sacrificed by decapitation. The adrenal glands were quickly excised and placed in Krebs-Ringer bicarbonate buffer (120 $\mathrm{mM} \mathrm{NaCl}, 1.5 \mathrm{mM} \mathrm{CaCl}_{2}, 4.8 \mathrm{mM} \mathrm{KCl}, 1.2 \mathrm{mM}$ $\mathrm{KH}_{2} \mathrm{PO}_{4}, 1.2 \mathrm{mM} \mathrm{MgSO}_{4}, 22 \mathrm{mM} \mathrm{NaHCO}$ and $0.2 \%$ glucose, $\mathrm{pH} 7.4)$ containing $1 \%$ bovine serum albumin (KRBGA). Fat tissues around the gland were trimmed off. The glands were cut into small pieces with a razor blade, and the fragments obtained from 30 adrenal glands were suspended in $10 \mathrm{ml}$ of KRBGA containing $2 \mathrm{mg} / \mathrm{ml}$ collagenase and $0.05 \mathrm{mg} / \mathrm{ml}$ deoxyribonuclease and incubated in an atmosphere of $95 \%$ air and $5 \% \mathrm{CO}_{2}$ for $45 \mathrm{~min}$ at $37^{\circ} \mathrm{C}$. The digested fragments were further dispersed by pipetting. The cell suspensions were centrifuged at $400 \times \mathrm{g}$ for $7 \mathrm{~min}$. The pellets were washed once by Krebs-Ringer bicarbonate buffer containing $4 \%$ bovine serum albumin and the recovered suspensions were filtered through a Nylon mesh to remove tissue debris. The free cell suspensions thus obtained were preincubated for $60 \mathrm{~min}$ at $37^{\circ} \mathrm{C}$ in an atmosphere of $95 \%$ air and $5 \% \mathrm{CO}_{2}$, then washed once, and resuspended in KRBGA. Viability of the cells, estimated in $0.04 \%$ Trypan-blue solution, was usually higher than $90 \%$. According to these procedures, approximately $3 \times 10^{5}$ viable cells were obtained from one adrenal gland.

Measurement of Steroidogenesis by Adrenocortical Cells and Determination of Cholesterol 
In a typical experiment, $5 \times 10^{5}$ cells were incubated with, or without, ACTH $(40 \mathrm{nM})$ in $1 \mathrm{ml}$ of KRBGA in an atmosphere of $95 \%$ air and $5 \% \mathrm{CO}_{2}$ for $60 \mathrm{~min}$. The incubation was terminated by centrifugation at $1,100 \times \mathrm{g}$ for 10 min. The supernatants were measured for steroid content by high performance liquid chromatography (HPLC) as described previously (Kim et al., 1983 ; Momoi et al., 1983 ; Yagi et al., 1983). The pellets were homogenized in $0.25 \mathrm{M}$ sucrose containing $10 \mathrm{mM}$ Tris- $\mathrm{HCl}$ and $1 \mathrm{mM}$ EDTA, pH 7.4, using a glass homogenizer with a teflon pestle. The homogenate was centrifuged at 900 $\times \mathrm{g}$ for $10 \mathrm{~min}$ and the supernatant fraction obtained was again centrifuged at $8,000 \times \mathrm{g}$ for $15 \mathrm{~min}$. The pellets recovered from the second centrifugation were used as the mitochondrial fraction. The mitochondrial pellets were frozen and thawed to disrupt the membrane. To the pellets $5 \alpha$-cholestane was added as an internal standard, and cholesterol was extracted with dichloromethane. Cholesterol was determined by gas chromatography using an $\mathrm{OV}-1$ column $(3 \mathrm{~mm}$ $\times 2 \mathrm{~m})$ at a column temperature of $250^{\circ} \mathrm{C}$ and an injector temperature of $270^{\circ} \mathrm{C}$. The content of the ester form of cholesterol was estimated as the difference between the cholesterol content after alkaline digestion $(1 \mathrm{M} \mathrm{KOH})$ of the sample and that before the saponification. The experiments were performed at least three times under the same incubation conditions. The average content of the mitochondrial cholesterol in the non-treated cells was $25.2 \pm 2.2 \mu \mathrm{g} / \mathrm{mg}$ protein.

\section{Preparation of Adrenocortical Mitochondria from Rats Suffering from Ether Stress}

This experiment was carried out in essentially the same way as described by Privalle et al (1983). Six rats were injected intraperitoneally with $10 \mathrm{mg}$ of aminoglutethimide dissolved in $1 \mathrm{ml}$ of saline. Control groups received saline alone. The animals were immediately transferred into a container saturated with ether gas, and maintained in anesthetic conditions for $20 \mathrm{~min}$. After the ether stress, the animals were killed and the adrenals were excised. The mitochondrial fractions were prepared from the whole adrenal glands in the manner described above.

\section{Freeze Fracture Electron Microscopy}

The mitochondrial pellets were fixed with $2 \%$ glutaraldehyde solution bufferred at $\mathrm{pH} 7.4$ with $0.1 \mathrm{M}$ cacodylate for 5-10 min, and treated with
0.02-0.05\% filipin contained in the same fixative for $12-24 \mathrm{~h}$ at room temperature. The samples were soaked in $30 \%$ glycerol solution for $20 \mathrm{~min}$ and rapidly frozen in melting nitrogen slush. The specimens were cleaved, shadowed with platinum-palladium, and stabilized with carbon in a JEOL-7000 type universal freeze specimen preparation device. The replicas made were examined in a Hitachi $\mathrm{H}-500$ type electron microscope.

\section{Protein Determination}

Protein concentration was determined in the manner described by Lowry et al. (1951) using bovine serum albumin as the standard.

\section{Results}

To establish the optimal conditions for ACTH-stimulation of the adrenocortical cell suspensions, various doses of ACTH were added to the cells, and steroids released in the medium were determined. The amount of corticosterone and 18-hydroxydeoxycorticosterone released was dependent on the concentration of ACTH in the incubation medium. Forty nM of ACTH was chosen as the optimal concentration for steroidogenesis. The time course of steroidogenesis was investigated. When the optimal dose of ACTH was added to the adrenocortical cell suspension, corticosterone release began after a time lag of $10-15 \mathrm{~min}$, continued linearly for the next $50 \mathrm{~min}$, and then gradually slowed down. From these results, the cells after the 90 min-incubation with ACTH were taken for analysis of cholesterol movement in the cells.

Aminoglutethimide is a well-known inhibitor of cytochrome P-450 scc. The effect of aminoglutethimide on the ACTH-stimulated steroidogenesis was examined. As shown in Table 1, $50 \mu \mathrm{M}$ of the drug seemed to be enough to inhibit the steroidogenesis caused by the optimal dose of ACTH.

Figure 1 shows the relative contents of the mitochodrial cholesterol under various incubation conditions of the adrenocortical 
Table 1. Effect of aminoglutethimide on steroidogenesis.*

\begin{tabular}{cccc}
\hline \hline ACTH & Aminoglutethimide & \multicolumn{2}{c}{ Steroid (nmol/90 min) } \\
\cline { 3 - 4 } $\mathrm{nM}$ & $\mu \mathrm{M}$ & Corticosterone & 18-Hydroxydeoxycorticosterone \\
\hline 40 & 0 & 42.0 & 14.0 \\
40 & 50 & 6.8 & 1.6 \\
40 & 100 & 3.3 & 1.0 \\
\hline
\end{tabular}

* The cells $\left(5 \times 10^{5}\right)$ were incubated with ACTH $(40 \mathrm{nM})$ in the presence, or absence, of aminoglutethimide for $90 \mathrm{~min}$, and the medium was analyzed for steroids as described in Materials and 1 Methods.

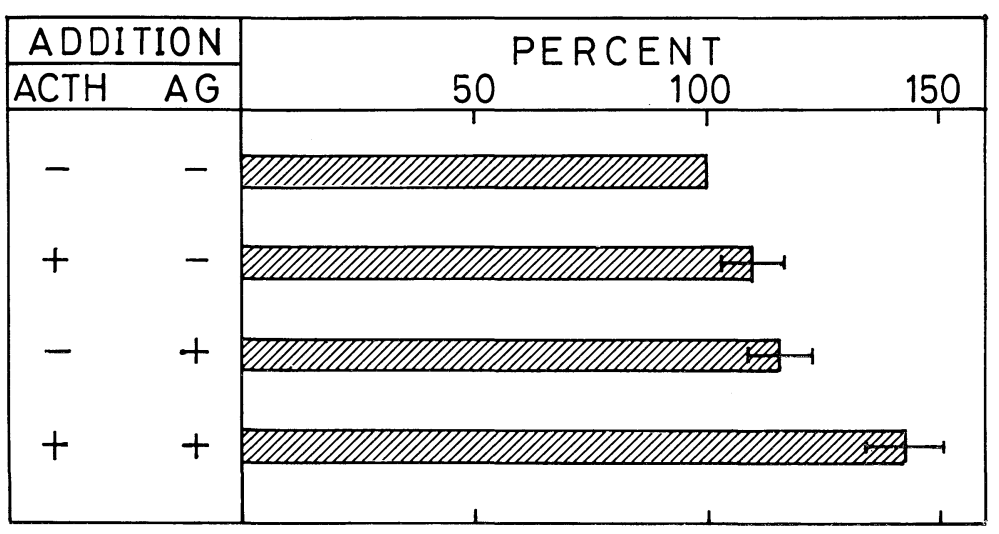

Fig. 1. Relative contents of cholesterol in adrenocortical mitochondria under various incubation conditions. The cells $\left(5 \times 10^{6}\right)$ were incubated with, or without, ACTH (40 nM) and aminoglutethimide (50 $\mu \mathrm{M})$ in $10 \mathrm{ml}$ of KRBGA for $90 \mathrm{~min}$, and the mitochondrial cholesterol contents were determined as described in Materials and Methods. The results are the means for three experiments and the bars represent standard deviations of the means. cells. The mitochondrial fraction of the rat adrenocortical cells in a resting state contained an appreciable amount of free cholesterol $(25.2 \mu \mathrm{g} / \mathrm{mg})$. When the cells were stimulated by ACTH under the optimal conditions, only a $10 \%$ increase in cholesterol content was observed. This result suggests that the cholesterol content in the mitochondria is in a nearly steady state during the ACTH-mediated steroidogenesis. If aminoglutethimide, an inhibitor of cholesterol side chain cleavage, was present in the incubation so that the steroidogenesis was prevented, a greater accumulation of cholesterol was observed in the mitochondria of ACTH-stimulated cells than in those of nonstimulated cells. The increase in cholesterol was about $43 \%$ compared to the cells without both ACTH and aminoglutethimide and about $23 \%$ compared to the cells treated with aminoglutethimide alone. Although a variety of the incubation times other than 90 min were tested, we could not find an accumulation of cholesterol greater than $150 \%$ in the stimulated cells when compared to the control cells.

The cholesterol ester content in the mitochondrial fraction was about $25 \mu \mathrm{g} / \mathrm{mg}$ protein, and no variation was observed under a variety of incubation conditions (data not shown).

Next, we studied the intramitochondrial accumulation of cholesterol during ether stress applied to the animal. Rats were pretreated by injecting aminoglutethimide and immediately transferred into a container saturated with ether gas. The animals were maintained under anesthetic conditions for $20 \mathrm{~min}$, and then the adrenal glands were excised and analyzed for cholesterol in the 
Table 2. Cholesterol content in the mitochondrial fraction of the adrenal cortex during ether stress of the animal.*

\begin{tabular}{lccc}
\hline \multicolumn{2}{c}{ Treatment } & \multicolumn{2}{c}{ Cholesterol content $\mu \mathrm{g} / \mathrm{mg}$ protein } \\
\hline Injection & Anesthesia & & \\
\hline & & Experiment I & Experiment II \\
Saline & Ether & $18.5(100)$ & $25.5(100)$ \\
Aminoglutethimide & Ether & $41.2(222)$ & $45.0(177)$ \\
\hline
\end{tabular}

* Six rats were injected with aminoglutethimide, and the animals were subjected to ether stress for $20 \mathrm{~min}$. Control rats received a saline injection and were exposed to ether. The mitochondrial pellets were prepared from adrenal glands and analyzed for cholesterol as described in Materials and Methods. The numbers in parentheses represent the percentages of the control.

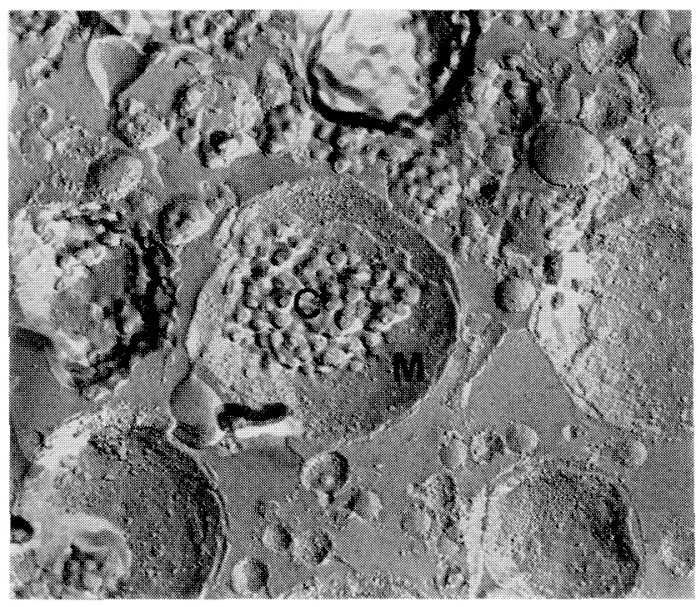

Fig. 2. Freeze-fracture image of mitochondria (M) of adrenocortical cells treated with filipin. Note the numerous filipin-cholesterol-complexes (C) in the inner mitochondrial membrane. $\times 37,500$

mitochondrial fractions. The results of two experiments are shown in Table 2. The pretreatment with aminoglutethimide caused the accumulation of cholesterol in the mitochondrial fraction during the ether stress. The increase was almost $100 \%$ compared to the non-treated control group.

With regard to these results obtained from the experiments conducted in vitro as well as in vivo on the mitochondrial fraction of rat adrenal glands, the following two points should be noted: (1) the mitochondria of rat adrenal cortex contained an appreciable amount of cholesterol, and (2) the cholesterol

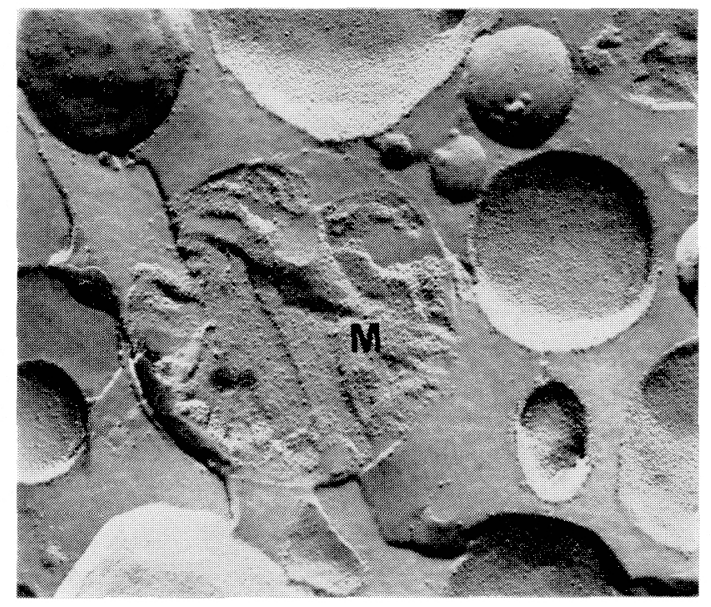

Fig. 3. Freeze-fracture image of mitochondria of rat liver cells treated with filipin under the same conditions as the treatment for adrenocortical mitochondria as described in Materials and Methods. $\times 37,500$

content in the mitochondria increased after the adrenocortical cells were stimulated with $\mathrm{ACTH}$ in vitro or by anesthetic stress in vivo, when aminoglutethimide, an inhibitor of side chain cleavage of cholesterol, was present.

To further confirm the presence of cholesterol in the adrenocortical mitochondria and to get more insight into the status of cholesterol in the mitochondrial membrane, the mitochondrial pellets were treated with filipin-containing fixing reagent and the samples were examined by means of a freezefracture method. A similar filipin-treatment was conducted on the rat liver mitochondrial 
pellets for the purpose of comparison. As shown in Fig. 2, the accumulations of numerous filipin-cholesterol complexes were found mainly in the inner membrane of about one third of the adrenocortical mitochondria as protuberances or pits of 25 to $30 \mathrm{~nm}$ in diameter. On the other hand, the rat liver mitochondria did not reveal any filipin-cholesterol complexes at all (Fig. 3).

\section{Discussion}

In this paper we first described the optimal conditions for ACTH-stimulated steroidogenesis of the rat adrenocortical cell suspensions. By conducting the incubation of $5 \times 10^{5}$ cells with $40 \mathrm{nM}$ ACTH (Cortrosyn) in $1 \mathrm{ml} \mathrm{KRBGA}$ for $90 \mathrm{~min}$, we were able to obtain the release from the cells of substantial amounts of corticosterone and 18-hydroxydeoxycorticosterone, which could be measured by HPLC. A use of HPLC for the measurement of corticosteroids would be easier than a cumbersome conventional radioimmunoassay.

After establishing the optimal conditions, we asked two questions concerning the behavior of cholesterol in the adrenocortical cells. The first question was whether cholesterol, the primary substrate of corticosteroids, moved into the mitochondria, the site of cholesterol side chain cleavage, during the steroidogenesis, and if so, whether or not its movement was regulated by ACTH. Our results suggested that an appreciable amount of cholesterol existed in the mitochondrial fractions of adrenocortical cells in a resting state, and the ACTH-stimulation in the presence of aminoglutethimide caused about a $40 \%$ of increase in cholesterol content in the mitochondria (Fig. 1). Jefcoate and colleagues, using the in vitro superfusion of rat adrenal cells (Crivello and Jefcoate, 1980) or the in vivo anesthetic stress of rats (Privalle et al., 1983), have reported that the cholesterol content in the mitochondrial fraction increased to about $180 \%$ in the steroid-producing adrenal glands compared to the non-producing glands. We also performed the experiments on the animals under the ether tress, and obtained similar results to those of Jefcoate et al. (Table 2). A discrepancy between the degree of accumulation of cholesterol on in vitro $(140 \%)$ and in vivo $(200 \%)$ stimulation should be explored in the future. A possible explanation may be that the adrenocortical cells in KRBGA were under the unphysiological conditions which could not supply cholesterol from the extracellular source, while the adrenal glands of the animal under the ether stress could obtain cholesterol from the circulation via a low-density lipoprotein pathway.

The second question we asked about the cholesterol in the adrenocortical mitochondria concerned the localization of free cholesterol in the submitochondrial fraction. This question was asked, because it is generally known that mitochondria of the non-steroidogenic tissues do not contain much cholesterol in their membrane. To answer this question, the mitochondrial pellets were treated with filipin-containing fixative, and examined by freeze fracture electron microscopy. The results clearly indicated the presence of filipin-cholesterol complexes in the inner membrane of mitochondria of the adrenocortical cells, which is the site of the ratedetermining reaction of steroidogenesis. Unfortunately, however, we could not find a significant morphological difference in the amount of the complexes between the mitochondria of the ACTH-stimulated cells and those of the non-stimulated cells. In contrast with these results, the liver mitochondria which had been treated with filipin under the same conditions as those for the adrenocortical mitochondria did not reveal the filipin-cholesterol complexes. These results are consistent with our previous observations obtained on other cells such as adrenal medullary cells, anterior pituitary cells, 
thyroid follicle cells, pancreatic exocrine cells and ovarian duct cells (Fujita et al., 1981; Fujita et al., 1982; Matsuda et al., 1983).

\section{Acknowledgements}

This work was supported in part by research grants from the Science and Technology Agency of Japan and from the Ministry of Health and Welfare of Japan.

\section{References}

Crivello J.F. and C.R. Jefcoate (1980). Intracellular movement of cholesterol in rat adrenal cells. J. Biol. Chem. 255, 8144-8151.

De Kruijff B. and R.A. Demel (1974). Polyene antibiotic-sterol interactions in membranes of Acholeplasma laidlawii cells and lecithin liposomes. III. Molecular structure of the polyene antibiotic-cholesterol complexes. Biochim. Biophys. Acta 339, 57-70.

Fujita H., K. Ishimura and H. Matsuda (1981). Freeze-fracture images on filipin-sterol complexes in the thyroid follicle epithelial cell of mice with special regard to absence of cholesterol at the site of micropinocytosis. Histochemistry 73, 57-63.

Fujita H., K. Ishimura, H. Matsuda and T. Ban (1982). Freeze-fracture images of distribution of filipin-cholesterol complexes in secretory cells of the anterior pituitary and adrenal medulla of mice. Acta Histochem. Cytochem. 15, 284-293.

Garren L.D., G.N. Gill, H. Masui and G.M. Walton (1971). On the mechanism of action of ACTH. Recent Progr. Hormone Res. 27, 433-474.

Hall P.F., S. Osawa and C.L. Thomasson (1981). A role for calmodulin in the regulation of steroidogenesis. J. Cell Biol. 90, 402-407.

Haning R., S. A. S. Tait and J. F. Tait (1970). In vitro effects of $\mathrm{ACTH}$, angiotensins, serotonin and potassium on steroid output and conversion of corticosterone to aldosterone by isolated adrenal cells. Endocrinology 87, 11471167.

Kido T. and T. Kimura (1981). Stimulation of cholesterol binding to steroid-free cytochrome p- $450_{\text {sec }}$ by poly (L-lysine). J. Biol. Chem.
256, 8561-8568

Kim C.Y., T. Sugiyama, M. Okamoto and T. Yamano (1983). Regulation of 18-hydroxycorticosterone formation in bovine adrenocortical mitochondria. J. Steroid Biochem. 18, 593599.

Kimura T. (1981). ACTH stimulation of cholesterol side chain cleavage activity of adrenocortical mitochondria. Mol. Cell. Biochem. 36, 105-122.

Kinsky S.C. (1970). Antibiotic interaction with model membranes. Annu. Rev. Pharmacol. 10, 119-142.

Lowry O.H., N.J. Rosebrough, A.L. Farr and R. J. Randall (1951). Protein measurement with the Folin phenol reagent. J. Biol. Chem. 193, 265-275.

Mahaffee D., R.C. Reitz and R.L. Ney (1974). The mechanism of action of adrenocorticotropic hormone. J. Biol. Chem. 249, 227-233.

Matsuda, H., H. Fujita and K. Ishimura (1983). Freeze-fracture images of distribution of filipincholesterol complexes in the oviduct epithelium of mice. Acta Histochem. Cytochem. 16, 112118.

Momoi K., M. Okamoto, S. Fujii, C.Y. Kim, Y. Miyake and T. Yamano (1983). 19-Hydroxylation of 18-hydroxy-11-deoxycorticosterone catalyzed by cytochrome P-450 $11 \beta$ of bovine adrenocortex. J. Biol. Chem. 258, 8855-8860.

Montesano R. (1979). Inhomogeneous distribution of filipin-sterol complexes in the ciliary membrane of rat tracheal epithelium (1). Am. J. Anat. 156, 139-145.

Nakajima Y. and P.C. Bridgman (1981). Absence of filipin-sterol complexes from the membranes of active zones and acetylcholine receptor aggregates at frog neuromuscular junctions. $J$. Cell Biol. 88, 453-458.

Norman A.W., A.M. Spielvogel and R.G. Wong (1976). Polyene antibiotic-sterol interaction. Adv. Lipid Res. 14, 127-170.

Ohno, Y., K. Yanagibashi, Y. Yonezawa, S. Ishiwatari and M. Matsuba (1983). A possible role of "Steroidogenic Factor" in the corticoidogenic response to ACTH ; effect of ACTH, cycloheximide and aminoglutethimide on the content of cholesterol in the outer and inner mitochondrial membrane of rat adrenal cortex. Endocrinol. Japon. 30, 335-338.

Privalle C. T., J. F. Crivello and C. R. Jefcoate (1983). Regulation of intramitochondrial cholesterol transfer to side-chain cleavage cyto- 
chrome $\mathbf{P}-450$ in rat adrenal gland. Proc. Natl. Acad. Sci. USA 80, 702-706.

Schulster D. (1974). Adrenocorticotrophic hormone and the control of adrenal corticosteroidogenesis. Adv. in Steroid Biochem. and Pharmacol. 4, 233-295.

Simpson E. R. (1979). Cholesterol side-chain cleavage, cytochrome $\mathrm{P}-450$, and the control of steroidogenesis. Mol. Cell. Endocrinol. 13, 213-227.

Simpson E.R., J.L. McCarthy and J.A. Peterson (1978). Evidence that the cycloheximidesensitive site of adrenocorticotropic hormone action is in the mitochondrion. J. Biol. Chem. 253, 3135-3139.

Stone D. and O. Hechter (1954). Studies on ACTH action in perfused bovine adrenals: The site of action of ACTH in corticosteroidogenesis. Arch. Biochem. Biophys. 51, 457-469.

Yagi J., T. Sugiyama, M. Okamoto, K. Kurachi and T. Yamano (1983). Zonal distribution of cytochrome $\mathrm{P}-450 \mathrm{~s}\left(\mathrm{P}-450_{11 \beta}\right.$ and $\left.\mathrm{P} 450_{\mathrm{scc}}\right)$ and their relation to steroidogenesis in bovine adrenal cortex. J. Steroid Biochem. 18, 707713. 